\section{RMD Open}

Rheumatic \&

Musculoskeletal Diseases

\title{
Pulmonary arterial hypertension, a novelty in idiopathic inflammatory myopathies: insights and first experiences with vasoactive therapy
}

\author{
Kavish J Bhansing, ${ }^{1}$ Anton Vonk-Noordegraaf, ${ }^{2}$ Frank PT Oosterveer, ${ }^{2}$ \\ Piet LCM van Riel, ${ }^{3}$ Madelon C Vonk ${ }^{1}$
}

To cite: Bhansing $\mathrm{KJ}$, Vonk-Noordegraaf A, Oosterveer FPT, et al. Pulmonary arterial hypertension, a novelty in idiopathic inflammatory myopathies: insights and first experiences with vasoactive therapy. RMD Open 2017:3:e000331. doi:10.1136/ rmdopen-2016-000331

- Prepublication history for this paper is available online. To view these files please visit the journal online (http://dx.doi. org/10.1136/rmdopen-2016000331).

Received 13 July 2016 Revised 5 January 2017 Accepted 5 February 2017

Published Online First 29 April 2017

\section{(a) CrossMark}

1Department of Rheumatology, Radboud University Medical Center, Nijmegen, The Netherlands

${ }^{2}$ Department of Pulmonary Diseases, VU University Medical Center, Amsterdam, The Netherlands

${ }^{3}$ Scientific Institute for Quality of Health Care, Radboud University Medical Center, Nijmegen, The Netherlands

Correspondence to MD Kavish J Bhansing; k.bhansing@reuma.umcn.nl

\section{ABSTRACT}

To characterise the different types of pulmonary hypertension $(\mathrm{PH})$ among idiopathic inflammatory myopathy (IIM). A retrospective case series with assessment of $\mathrm{PH}$ by right heart catheterisation, extent of interstitial lung disease (ILD) and outcome of vasoactive therapy. The group of patients with IIM with $\mathrm{PH}(\mathrm{n}=9)$ showed a median age at PH diagnosis of 62 years (IQR 48-71 years; eight women), seven diagnosed with polymyositis and two with dermatomyositis; median disease duration of 5.7 years and five patients with a positive anti-J01 antibody. We found one patient to be classified in PH WHO group 2 (left heart disease), five patients in WHO group 3 (lung disease) and three patients in WHO group 1 (pulmonary arterial hypertension (PAH)). During median observed follow-up of 24 months, mortality for the total group was $44 \%$. Surprisingly, we found a relevant group (33\%) of patients with IIM who suffered from non-ILD-PH, which reflects the presence of PAH phenotype. This result should lead to more awareness among treating physicians that complaints of dyspnoea among patient with IIM could be related to PAH and not only ILD. The role of vasoactive therapy remains to be defined in patients with IIM suffering from PAH or PH-ILD.

\section{INTRODUCTION}

Pulmonary hypertension (PH) is a life-threatening condition presenting with symptoms like breathlessness, fatigue and syncope. $\mathrm{PH}$ can occur as a complication of systemic autoimmune diseases. ${ }^{2-4}$ The association with polymyositis (PM) and dermatomyositis $(\mathrm{DM})$, together classified as idiopathic inflammatory myopathy (IIM), is not well known. So far, only a few cases reported on $\mathrm{PH}$ in patients with IIM. ${ }^{6-11}$ However, two recent cohort studies among antisynthetase patients revealed a prevalence of $\mathrm{PH}$ ranging from $7.9 \%$ to $14.8 \%$ with a worsened prognosis. ${ }^{12} 13$ These study results reflect the clinical relevance of $\mathrm{PH}$ as a complication of IIM.

\section{Key messages}

What is already known about this subject?

- Pulmonary hypertension (PH) is a life-threatening condition and is associated with patients with idiopathic inflammatory myopathy (IIM). Although interstitial lung disease (ILD) is frequently found among patients with IIM patients, the question is whether this lung disease explains the presence of $\mathrm{PH}$ in all patients with IIM.

What does this study add?

- Surprisingly, we found a relevant group (33\%) of patients with IIM who suffered from non-ILD-PH, which reflects the presence of pulmonary arteria hypertension (PAH) phenotype. The role of vasoactive therapy remains to be defined in patients with IIIM suffering from PAH or PH-ILD.

How might this impact on clinical practice?

- This result should lead to more awareness among treating physicians that complaints of dyspnoea among patients with IIM could be related to PAH and not only ILD.

Patients with $\mathrm{PH}$ can be classified according to the WHO classification in pulmonary arterial hypertension (PAH) (group 1), $\mathrm{PH}$ associated to left heart disease (group 2), $\mathrm{PH}$ associated to lung disease (group 3), chronic thromboembolic PH (group 4) and $\mathrm{PH}$ with unclear mechanism (group 5). ${ }^{14}$ The cause of $\mathrm{PH}$ in patients with IIM is however still unclear. Although interstitial lung disease (ILD) is frequently found among patients with IIM, occurring in up to $65 \%$ of the patients, ${ }^{15}$ the question is whether this lung disease explains the presence of $\mathrm{PH}$ in all patients with IIM. In addition, data on long-term follow-up are scarce.

For this, we describe the clinical characteristics and follow-up of nine patients with IIM 
with $\mathrm{PH}$ and investigated the cause and effect of $\mathrm{PH}$ in these patients.

\section{METHODS}

This is a retrospective case series which consisted of patients with IIM $(n=9)$ with PH of two Dutch university hospitals (Radboud University Medical Center, Nijmegen) $(\mathrm{n}=4)$ and (VU University Medical Center, Amsterdam) $(\mathrm{n}=5)$ which are both expert centres for $\mathrm{PH}$. According to Dutch law and regulations, the study was exempted from approval of a medical ethical committee and no informed consent was required since this was an observational, non-interventional study.

\section{Participants}

All patients with IIM fulfilled at least the criteria for probable IIM according to the European Neuromuscular Centre (ENMC) classification criteria. ${ }^{16} \mathrm{PH}$ was defined as an increase in mean pulmonary arterial pressure (mPAP) $\geq 25 \mathrm{~mm} \mathrm{Hg}$ assessed with right heart catheterisation (RHC).${ }^{14}$ All known patients with IIM and PH were included at both medical centres (VU University Medical Center, a registry of patients with $\mathrm{PH}$; Radboud University Medical Center, Myositis Nijmegen cohort).

\section{Interstitial lung disease}

Presence of extensive ILD was defined as signs of pulmonary fibrosis on high-resolution computed tomography (HRCT) scan with $>10 \%$ lung involvement. Limited ILD was defined as extent of lung parenchymal involvement $\leq 10 \%$ on HRCT which is a conservative cut-off in comparison with staging system of Goh et al $(\leq 20 \%) \cdot{ }^{17} \mathrm{In}$ remaining cases with an indeterminate extent on HRCT, an abnormal pulmonary function test (total lung capacity (TLC) $<70 \%$ predicted) was used to classify extensive ILD. A blinded pulmonologist (AV-N) retrospectively reviewed all available HRCT scans using the Wells method to score the presence and extent of ILD. ${ }^{18}$

\section{Haemodynamics RHC}

Based on pulmonary capillary wedge pressure (PCWP), $\mathrm{PH}$ can be divided into precapillary $\mathrm{PH}$ (PCWP $\leq 15 \mathrm{~mm}$ $\mathrm{Hg}$ ) and postcapillary $\mathrm{PH}$ (PCWP $>15 \mathrm{~mm} \mathrm{Hg}$ ), which can be related to different clinical causes. ${ }^{14}$ Patients with precapillary PH and limited ILD were defined as non-ILD-PH (reflecting PAH), whereas patients with precapillary $\mathrm{PH}$ and extensive ILD as ILD-PH. Other parameters which were assessed by RHC were PCWP, cardiac output and pulmonary vascular resistance (PVR). Outcome of vasoactive therapy in patients with PH-IIM was evaluated by available information on mortality, hospital admissions, therapy adjustments and alterations of 6 min walking test (6MWT) or WHO functional class (WHO-FC). ${ }^{19}$ The WHO-FC system grades severity of limitations due to $\mathrm{PH}$ on a scale of 1 (no limitations) to 4 (limitation of all exercise).

\section{CASE REPORT}

\section{Patients}

Our cohort consists of nine patients, of which seven patients were diagnosed with polymyositis and two with dermatomyositis. The median age at diagnosis of $\mathrm{PH}$ was 62 years (IQR 48-68 years; eight women). The median disease duration of IIM at diagnosis of PH was 5.7 years (IQR 3-10.3 years). In five patients, anti-Jo1 autoantibody was present (table 1 ).

\section{Interstitial lung disease}

Signs of pulmonary fibrosis on HRCT scans were present in seven patients (88\%), with scans performed in eight out of nine patients. All seven patients had a precapillary PH. A Wells score of 3, presenting dominance of a reticular pattern (ie, fibrosis) was present in three $(38 \%)$ patients. The median lung involvement was $50 \%$ of the surface (range 0\%-90\%) with four patients $\geq 70 \%$ lung involvement on the scans. Three patients (37\%) displayed none or limited lung involvement (surface $\leq 10 \%$ ) (table 1 , patients 3,5 and 9 ).

\section{PH characterisation}

Eight patients presented with precapillary PH. Chronic thromboembolic $\mathrm{PH}$ and multifactorial $\mathrm{PH}$ causes were excluded. One patient was diagnosed with postcapillary $\mathrm{PH}$ caused by severe aorta valve stenosis, $\mathrm{PH}$ WHO group 2 (table 1).

Combining information on ILD with RHC data demonstrates that five out of eight precapillary patients with $\mathrm{PH}$ had a fair to severe lung fibrosis, while the other three patients had none to limited lung fibrosis. Those three patients were diagnosed with PAH associated to IIM, WHO group 1 (patients 3, 5 and 9). In these patients, pulmonary fibrosis was either absent or present in $<10 \%$ of the pulmonary surface (table 1 ). The remaining five patients with fair to severe pulmonary fibrosis were classified as PH caused by ILD (PH-ILD), WHO group $3 .^{14}$

\section{Outcome}

The total group of patients with IIM and PH revealed a mortality of four patients (44\%) during a median observed follow-up of 16 months. Within 5 months of diagnosis of $\mathrm{PH}$, two patients died (patients 4 and 5), one due to heart failure complicated by severe aorta valve stenosis. The other patients died as a result of respiratory failure complicated with pneumonia before vasoactive therapy could be started.

Vasoactive therapy was initiated in seven patients with precapillary $\mathrm{PH}$ (table 2). Therapy included the use of prostanoids, endothelin receptors antagonists and phosphodiesterase type-5 inhibitors. Follow-up information was unavailable in one patient due to transfer to another hospital (patient 8). After the start of therapy, two patients revealed an increase of walking distance (18\% and 9\%) during $6 \mathrm{~min}$ walking test after 2 and 12 months (patients 2 and 3). However, after initial improvement, one patient died 3 years later due to heart 
Table 1 Clinical and haemodynamic characteristics of each patient at $\mathrm{PH}$ diagnosis

\begin{tabular}{|c|c|c|c|c|c|c|c|c|c|}
\hline Characteristics & Patient 1 & Patient 2 & $\begin{array}{l}\text { Patient } \\
3\end{array}$ & Patient 4 & Patient 5 & Patient 6 & Patient 7 & Patient 8 & $\begin{array}{l}\text { Patient } \\
9\end{array}$ \\
\hline Clinical characteristics & PM & PM & PM & $\begin{array}{l}\text { PM } \\
\text { overlap } \\
\text { SLE }\end{array}$ & $\mathrm{DM}$ & DM & PM & PM & PM \\
\hline ANA & + & + & + & + & + & - & + & + & - \\
\hline Anti-Jo1 & + & + & - & - & NA & + & + & - & + \\
\hline $\begin{array}{l}\text { Raynaud's } \\
\text { phenomenon }\end{array}$ & + & + & - & - & - & + & + & + & - \\
\hline Arthritis (history) & + & + & + & - & + & + & + & + & - \\
\hline $\begin{array}{l}\text { Disease duration } \\
\text { (years) }\end{array}$ & 20.4 & 8.8 & 5.1 & 1.2 & 5.8 & 0.6 & 10 & 5.4 & 10.7 \\
\hline $\begin{array}{l}\text { WHO functional } \\
\text { class }\end{array}$ & 2 & 3 & 2 & 4 & 4 & 3 & 2 & 3 & 3 \\
\hline WHO PH group & 3 & 3 & 1 & 2 & 1 & 3 & 3 & 3 & 1 \\
\hline \multicolumn{10}{|l|}{ HRCT scan } \\
\hline $\begin{array}{l}\text { Lung fibrosis on } \\
\text { HRCT }\end{array}$ & + & + & + & NA & - & + & + & + & + \\
\hline Wells score & 2 & 3 & 2 & NA & 0 & 2 & 3 & 1 & 3 \\
\hline $\begin{array}{l}\text { Lung involvement } \\
(\%)\end{array}$ & 70 & 70 & 10 & NA & 0 & 90 & 30 & 90 & 10 \\
\hline Extent of ILD & Extensive & Extensive & Limited & Extensive & Limited & Extensive & Extensive & Extensive & Limited \\
\hline \multicolumn{10}{|l|}{$\begin{array}{l}\text { Pulmonary function } \\
\text { test }\end{array}$} \\
\hline $\begin{array}{l}\text { TLC (\% of } \\
\text { predicted) }\end{array}$ & 66 & 80 & 64 & 57 & 51 & 87 & 65 & 50 & 105 \\
\hline $\begin{array}{l}\text { DLCO (\% of } \\
\text { predicted) }\end{array}$ & 66 & 53 & 68 & NA & 39 & 67 & 69 & 62 & 42 \\
\hline 6 Min walking test $(m)$ & NA & 143 & 420 & NA & NA & NA & 308 & 235 & 307 \\
\hline \multicolumn{10}{|l|}{$\mathrm{RHC}$} \\
\hline Mean PAP (mm Hg) & 45 & 40 & 66 & 41 & 60 & 32 & 25 & 33 & 52 \\
\hline PCWP (mm Hg) & 12 & 5 & 7 & 35 & 1 & 14 & 11 & 14 & 14 \\
\hline $\begin{array}{l}\text { Cardiac index }(\sqcup / \\
\left.\min / \mathrm{m}^{2}\right)\end{array}$ & NA & NA & 2.3 & 1.4 & 2.2 & 2.6 & 2.5 & NA & 2.1 \\
\hline $\begin{array}{l}\text { Cardiac output (L/ } \\
\text { min) }\end{array}$ & NA & 3.8 & 5.1 & 3.1 & 2.7 & 4.6 & 4.6 & 3.3 & 3.3 \\
\hline PVR (dynes/s/cm5) & NA & 743 & 928 & 155 & 1749 & 315 & 242 & 461 & 109 \\
\hline
\end{tabular}

ANA, antinuclear antibody; DLCO, diffusing capacity for carbon monoxide; DM, dermatomyositis; ILD, interstitial lung disease; PAP, pulmonary arterial pressure; PCWP, pulmonary capillary wedge pressure; PH, pulmonary hypertension; PM, polymyositis; PVR, pulmonary vascular resistance; RHC, right heart catheterisation; SLE, systemic lupus erythematosus; TLC, total lung capacity; NA, not available.

failure (patient 3). Stabilisation of walking distance after 6 months was observed in one patient. After 2 years, the patient died due to respiratory failure (patient 7). In one patient, pulmonary haemodynamics returned to normal after 1 year of therapy with bosentan (patient 6). The remaining two patients on $\mathrm{PH}$ therapy suffered from a slow progression on the WHO-FC (patients 1 and 9).

\section{DISCUSSION}

In this clinical case series, we describe a group of nine patients with PH-IIM followed at two referral centres for
$\mathrm{PH}$. We found one patient to be classified as $\mathrm{PH}, \mathrm{WHO}$ group 2 (left heart disease), five patients in WHO group 3 (lung disease) and three patients in WHO group 1 (PAH). Our study confirms previous results, indicating that the majority of the $\mathrm{PH}$ in IIM can be classified as PH-ILD, WHO group $3 .^{6-12}$ However, PAH associated to IIM is a possibility, in this group occurring in $33 \%$ of the patients.

The pathogenesis of PAH in IIM is unknown; however, involvement of pulmonary vessels by diffuse infiltrative and inflammatory processes is likely to contribute. ${ }^{5}$ An 


\begin{tabular}{|c|c|c|c|c|c|c|c|}
\hline Patient & $\begin{array}{l}\text { Therapy at } \\
\text { diagnosis }\end{array}$ & $\begin{array}{l}\text { WHO-FC at } \\
\text { PH diagnosis }\end{array}$ & $\begin{array}{l}\text { Therapy } \\
\text { adjustments }\end{array}$ & $\begin{array}{l}\text { Observed } \\
\text { follow-up } \\
\text { (months) }\end{array}$ & $\begin{array}{l}\text { Description } \\
\text { outcome }\end{array}$ & $\begin{array}{l}\text { WHO-FC at } \\
\text { end follow- } \\
\text { up }\end{array}$ & $\begin{array}{l}\text { Final } \\
\text { outcome }\end{array}$ \\
\hline 1 & $\mathrm{~S}$ & 2 & $\begin{array}{l}\mathrm{S} \uparrow: 18 \text { months } \\
\mathrm{S} \uparrow: 36 \text { months }\end{array}$ & 36 & $\begin{array}{l}\text { Slow progression to } \\
\text { WHO-FC } 3\end{array}$ & 3 & Alive \\
\hline 2 & $S$ & 3 & $\begin{array}{l}\mathrm{S}+\mathrm{I}: 12 \\
\text { months }\end{array}$ & 16 & $\begin{array}{l}\text { Remains at WHO- } \\
\text { FC } 3 \text { after iloprost } \\
\text { therapy }\end{array}$ & 3 & Alive \\
\hline 3 & B & 2 & $\begin{array}{l}B+S: 7 \\
\text { months } \\
B+S+T: 24 \\
\text { months }\end{array}$ & 36 & $\begin{array}{l}\text { Slow progression to } \\
\text { WHO-FC } 3 \\
6-M W T \text { at diagnosis } \\
420 \mathrm{~m} \text {, at } 8 \\
\text { months } 459 \mathrm{~m} \text {, at } \\
28 \text { months } 390 \mathrm{~m}\end{array}$ & 4 & $\begin{array}{l}\text { Death due } \\
\text { to heart } \\
\text { failure after } \\
36 \text { months }\end{array}$ \\
\hline 6 & B & 3 & $\mathrm{~B} \uparrow: 48$ months & 48 & $\begin{array}{l}\text { With bosentan } \\
\text { no PH after } 12 \\
\text { months, after } 48 \\
\text { months progressive } \\
\text { dyspnoea }\end{array}$ & NA & Alive \\
\hline 7 & $S$ & 2 & $\begin{array}{l}\text { Stop S: } 8 \\
\text { months }\end{array}$ & 24 & $\begin{array}{l}\text { Exacerbation of } \\
\text { PM after } 8 \text { months, } \\
\uparrow \text { prednisone and } \\
\text { start tacrolimus }\end{array}$ & 4 & $\begin{array}{l}\text { Death due to } \\
\text { respiratory } \\
\text { failure after } \\
24 \text { months }\end{array}$ \\
\hline 8 & $S$ & 3 & NA & 0 & $\begin{array}{l}\text { Unknown due to } \\
\text { transfer to other } \\
\text { hospital }\end{array}$ & NA & NA \\
\hline 9 & $A$ & 3 & $\begin{array}{l}\text { Diuretics: } 2 \\
\text { months }\end{array}$ & 12 & $\begin{array}{l}\text { Short hospitalisation } \\
\text { after } 2 \text { months due } \\
\text { to heart failure, after } \\
12 \text { months stable in } \\
\text { WHO-FC } 3\end{array}$ & 3 & Alive \\
\hline
\end{tabular}

A, ambrisentan; B, bosentan; I, iloprost inhalation; S, sildenafil; T, treprostinil; $\uparrow$, increase of dose; WHO-FC, WHO functional class; 6-MWT, 6 min walking test; PM, polymyositis; NA, not available.

autopsy study among patients with PM found suggestive changes for PAH by encroachment of the pulmonary blood vessel lumen with medial smooth muscle hyperplasia. ${ }^{20}$ More recently, a Swedish study demonstrated that sera of anti-Jo1-positive patients with PM could activate endothelial cells in healthy lung tissue. ${ }^{21}$ Altogether, these findings reinforce the hypothesis of specific pulmonary vascular involvement in the aetiology of $\mathrm{PH}$ among patients with IIM and the role of anti-tRNA synthetase autoantibodies such as anti-Jo1. ${ }^{512} 2021$

Interestingly, two out of the three patients with PAH revealed the lowest diffusing capacity for carbon monoxide (DLCO) values in our study. This observation tends to suggest, conversely to PAH among patients with systemic sclerosis, that patients with IIM with PAH are associated with low DLCO values in pulmonary function test. $^{22} 23$

Although small retrospective studies suggested that specific PAH therapy may be used in the presence of severe $\mathrm{PH}$ due to chronic lung disease, the benefit of this therapy still has to be demonstrated. In our cohort, initiation of PAH treatment was performed on the discretion of the treating doctor, including six patients with ILD and one patient without ILD. Although our observations suggest that some of our patients seem to benefit from such an approach, the uncontrolled nature of this observational study does not allow to draw any conclusions on the effectiveness of such an approach in PAH.

A recent French observational study showed a 3-year survival of $58 \%$ in patients with $\mathrm{PH}$ antisynthetase. ${ }^{12}$ The overall mortality in our study was $44 \%$ which suggests that the presence of $\mathrm{PH}$ was associated with a worse survival.

The strength of our study is the novelty of reporting cases of PAH among patients with IIM with complete RHC data.

A limitation of our study is that all patients were recruited from two tertiary referral $\mathrm{PH}$ expert centres, which could have led to a selection bias. However, to study an uncommon complication $(\mathrm{PH})$ in a rare disease (IIM) inevitably leads to multicentre recruitment at tertiary centres. Furthermore, limited serology data were available by which proper classification of the presence of antisynthetase syndrome and further determination of antinuclear antibody positivity was not possible. 
In conclusion, in this study, we found the presence of ILD-PH in the majority (55\%) of the selected patients with IIM and PH. Surprisingly, a relevant group (33\%) of patients with IIM suffered from non-ILD-PH, which reflects the presence of $\mathrm{PAH}$ phenotype on which connective tissue disease itself plays a role in the aetiology. Vasoactive therapy could play a role in the treatment of patients with IIM and PAH phenotype. Altogether, this result should lead to more awareness among treating physicians that complaints of dyspnoea among patients with IIM could be related to PAH and not only ILD. Given the rarity of PH-IIM, a joined international effort is required to obtain more insights in the different $\mathrm{PH}$ phenotypes and the optimal treatment strategy of this disease.

Competing interests None declared.

Provenance and peer review Not commissioned; externally peer reviewed.

Open Access This is an Open Access article distributed in accordance with the Creative Commons Attribution Non Commercial (CC BY-NC 4.0) license, which permits others to distribute, remix, adapt, build upon this work non-commercially, and license their derivative works on different terms, provided the original work is properly cited and the use is non-commercial. See: http://creativecommons.org/ licenses/by-nc/4.0/

(C) Article author(s) (or their employer(s) unless otherwise stated in the text of the article) 2017. All rights reserved. No commercial use is permitted unless otherwise expressly granted.

\section{REFERENCES}

1. Vonk MC, van Dijk AP, Heijdra YF, et al. Pulmonary hypertension: its diagnosis and management, a multidisciplinary approach. Neth $J$ Med 2005;63:193-8.

2. Proudman SM, Stevens WM, Sahhar J, et al. Pulmonary arterial hypertension in systemic sclerosis: the need for early detection and treatment. Intern Med J 2007;37:485-94.

3. Bull TM, Fagan KA, Badesch DB. Pulmonary vascular manifestations of mixed connective tissue disease. Rheum Dis Clin North Am 2005;31:451-64.

4. Heresi GA, Minai OA. Lupus-associated pulmonary hypertension: long-term response to vasoactive therapy. Respir Med 2007;101:2099-107.

5. Lega JC, Reynaud Q, Belot A, et al. Idiopathic inflammatory myopathies and the lung. Eur Respir Rev 2015;24:216-38.

6. Yaqub S, Moder KG, Lacy MQ. Severe, reversible pulmonary hypertension in a patient with monoclonal gammopathy and features of dermatomyositis. Mayo Clin Proc 2004;79:687-9.

7. Minai OA. Pulmonary hypertension in polymyositis-dermatomyositis: clinical and hemodynamic characteristics and response to vasoactive therapy. Lupus 2009;18:1006-10.
8. Taniguchi Y, Horino T, Kato T, et al. Acute pulmonary arterial hypertension associated with anti-synthetase syndrome. Scand $J$ Rheumatol 2010;39:179-80.

9. Chatterjee S, Farver C. Severe pulmonary hypertension in Anti-Jo-1 syndrome. Arthritis Care Res 2010;62:425-9.

10. Handa T, Nagai S, Kawabata D, et al. Long-term clinical course of a patient with anti PL-12 antibody accompanied by interstitial pneumonia and severe pulmonary hypertension. Intern Med 2005;44:319-25.

11. Cavagna L, Prisco E, Montecucco C, et al. Pulmonary arterial hypertension in antisynthetase syndrome: comment on the article by Chatterjee and Farver. Arthritis Care Res 2011;63:633-4.

12. Hervier B, Meyer A, Dieval C, et al. Pulmonary hypertension in antisynthetase syndrome: prevalence, aetiology and survival. Eur Respir J 2013;42:1271-82.

13. Aggarwal R, Cassidy E, Fertig N, et al. Patients with non-Jo-1 anti-tRNA-synthetase autoantibodies have worse survival than Jo-1 positive patients. Ann Rheum Dis 2014;73:227-32.

14. Galiè N, Humbert M, Vachiery JL, et al. 2015 ESC/ERS guidelines for the diagnosis and treatment of pulmonary hypertension: the Joint Task Force for the diagnosis and treatment of pulmonary hypertension of the European Society of Cardiology (ESC) and the European Respiratory Society (ERS): Endorsed by: Association for European Paediatric and Congenital Cardiology (AEPC), International Society for Heart and Lung Transplantation (ISHLT). Eur Respir J 20152015;46:903-75;46:903-75.

15. Labirua A, Lundberg IE. Interstitial lung disease and idiopathic inflammatory myopathies: progress and pitfalls. Curr Opin Rheumatol 2010;22:633-8.

16. Hoogendijk JE, Amato AA, Lecky BR, et al. 119th ENMC international workshop: trial design in adult idiopathic inflammatory myopathies, with the exception of inclusion body myositis, 10-12 October 2003, Naarden, The Netherlands. Neuromuscul Disord 2004;14:337-45

17. Goh NS, Desai SR, Veeraraghavan S, et al. Interstitial lung disease in systemic sclerosis: a simple staging system. Am J Respir Crit Care Med 2008;177:1248-54.

18. Wells AU, Hansell DM, Rubens MB, et al. The predictive value of appearances on thin-section computed tomography in fibrosing alveolitis. Am Rev Respir Dis 1993;148(4 Pt 1):1076-82.

19. McGoon M, Gutterman D, Steen V, et al. Screening, early detection, and diagnosis of pulmonary arterial hypertension: accp evidence-based clinical practice guidelines. Chest 2004;126(1 Suppl):14S-34

20. Denbow CE, Lie JT, Tancredi RG, et al. Cardiac involvement in polymyositis: a clinicopathologic study of 20 autopsied patients. Arthritis Rheum 1979;22:1088-92.

21. Barbasso Helmers S, Englund P, Engström M, et al. Sera from antiJo-1-positive patients with polymyositis and interstitial lung disease induce expression of intercellular adhesion molecule 1 in human lung endothelial cells. Arthritis Rheum 2009;60:2524-30.

22. Hachulla E, Gressin V, Guillevin L, et al. Early detection of pulmonary arterial hypertension in systemic sclerosis: a French nationwide prospective multicenter study. Arthritis Rheum 2005;52:3792-800.

23. Mukerjee D, St George D, Knight C, et al. Echocardiography and pulmonary function as screening tests for pulmonary arterial hypertension in systemic sclerosis. Rheumatology 2004;43:461-6. 